\title{
DO ANTIBACTERIAL MILK CONSTITUENTS INTERFERE WITH MICROBIOLOGICAL EXAMINATION OF CLINICAL MASTITIS?
}

\author{
B.-A. Tenhagen ${ }^{1}$, H. Schmedt auf der Günne ${ }^{1}$, P. Kutzer ${ }^{2}$, D. Forderung ${ }^{1}$, W. Heuwieser ${ }^{1}$ \\ Free University of Berlin, ${ }^{1}$ Clinic for Reproduction, Section of Herd Health and Quality Management \\ and ${ }^{2}$ Institute of Microbiology
}

www.bestandsbetreuung.de

Bacteria are the main causative agents of clinical mastitis. However, 10 to $40 \%$ of milk samples obtained from mastitic quarters are negative on culture. Lactoferrin, lysozyme and the lactoperoxidase system (LPS) are milk ingredients that are known to inhibit bacterial growth. It was the objective of this study, to analyse the possible role of lactoferrin, lysozyme and the lactoperoxidase system as growth inhibitors in milk samples from quarters with clinical mastitis.

Lactating dairy cows $(n=75)$ with clinical mastitis on a commercial dairy farm were included in the study. Cows were examined clinically and milk samples were collected from the quarter affected by clinical mastitis (clinical quarter) and the opposite quarter (control quarter). Samples were submitted for microbiological examination and were tested for activity of the LPS using spectrophotometry. Samples were stored at $-20^{\circ} \mathrm{C}$ until examined for concentration of lactoferrin using an ELISA. Lysozyme was determined using the "lyso plate" technique (inhibibition of growth of Micrococcus lysodeicticus suspended in agar).

Contents of all three milk constituents were significantly higher in the samples collected from clinical quarters than from control quarters. Clinical signs were on average more severe in cows with positive samples than in those with negative samples. Lactoferrin content and LPS activity did not differ between samples that yielded bacterial growth (positive samples) on culture and sterile samples. Lysozyme content was even higher in positive than in negative samples.

Table 1: Contents or activity of the milk constituents under study in positive, negative and control samples.

\begin{tabular}{lccc}
\hline & Positive samples & Negative samples & Control samples \\
\hline Lactoferrin $(\mathrm{mg} / \mathrm{ml})$ & $0,13 \pm 0,13^{\mathrm{b}}$ & $0,12 \pm 0,05^{\mathrm{b}}$ & $0,07 \pm 0,04^{\mathrm{a}}$ \\
Lysozyme $(\mu \mathrm{g} / \mathrm{ml})$ & $1,81 \pm 1,60^{\mathrm{c}}$ & $0,92 \pm 1,01^{\mathrm{b}}$ & $0,47 \pm 0,52^{\mathrm{a}}$ \\
LPO-activity $(\mathrm{U} / \mathrm{l})$ & $1466 \pm 644^{\mathrm{b}}$ & $1448 \pm 465^{\mathrm{b}}$ & $1315 \pm 546^{\mathrm{a}}$ \\
\hline
\end{tabular}

$a, b, c$ values in rows with different indices differ significantly $(\mathrm{p}<0.05)$

It is concluded that the three milk constituents measured play a negligible role in the origin of the failure to identify the causative agent of mastitis cases in dairy cows. 